\title{
Peningkatan Hasil Belajar Matematika Pokok Bahasan Volume Kubus dan Balok melalui Pendekatan Kontekstual bagi Siswa Kelas V di SD Inpres 33 Kabupaten Sorong
}

\author{
Saniyah Saniyah \\ SD Inpres 33 Kabupaten Sorong \\ saniyah21@gmail.com
}

\begin{abstract}
Abstrak: Penelitian ini bertujuan untuk mengetahui peningkatan Hasil Belajar Matematika Pokok Bahasan Volume kubus dan balokbagi Siswa Kelas V di SD Inpres 33 Kabupaten Sorong melalui Pendekatan Kontekstual. Jenis penelitian ini adalah penelitian tindakan kelas (Classroom Action and Research) yang dilakukan secara kolaboratif antara peneliti dengan guru. Subyek penelitian adalah seluruh siswa kelas V pada Semester Ganjil Tahun Pelajaran 2017/2018 dengan siswa sebanyak 30 orang. Pada pelaksanaannya yang terdiri dari 2 siklus, yaitu Siklus I dilaksanakan selama empat kali pertemuan dan Siklus II dilaksanakan selama empat kali pertemuan. Pengambilan data dilakukan dengan menggunakan Tes Akhir Siklus dan Observasi. Hasil belajar matematika siswa kelas V pada Semester Ganjil Tahun Pelajaran 2017/2018 meningkat setelah dilakukan pembelajaran dengan pendekatan kontekstual selama dua siklus dengan hasil sebagai berikut : (1) Hasil belajar matematika siswa sebelum pembelajaran dengan pendekatan kontekstual berada dalam kategori rendah dengan nilai ratarata 50,66 dari nilai tertinggi 70 dan nilai terendah 20. (2) Hasil belajar matematika siswa setelah pembelajaran Siklus I dengan pendekatan kontekstual dengan nilai rata-rata 58,66 dari nilai tertinggi 80 dan nilai terendah 40. (3). Hasil belajar matematika siswa setelah pembelajaran dengan pendekatan kontekstual Siklus II berada dalam kategori sedang dengan nilai rata-rata 68,67 dari nilai tertinggi 100 dan nilai terendah 50.

Kata Kunci: hasil belajar matematika, pendekatan kontekstual, dan volume kubus dan balok
\end{abstract}

Abstract: This study aims to determine the increase in the Main Mathematics Learning Outcomes of the Volume of cubes and beams for Class V Students at SD Inpres 33 of Sorong Regency through a Contextual Approach. The type of this research is classroom action research (Research) which is carried out collaboratively between researchers and teachers. The subjects of the study were all fifth grade students in the Odd Semester 2017/2018 Academic Year with as many as 30 students. In its implementation consisting of 2 cycles, namely Cycle I was held for four meetings and Cycle II was held for four meetings. Data retrieval is done by using Cycle and Observation Final Tests. Grade V mathematics learning outcomes in the 2017/2018 Odd Semester Academic Year increased after learning with a contextual approach for two cycles with the following results: (1) Student mathematics learning outcomes before learning with contextual approaches are in the low category with an average value 50.66 from the highest score of 70 and the lowest value 20. (2) The results of student mathematics learning after Cycle I learning with a contextual approach with an average value of 58.66 from the highest value of 80 and the lowest value 40. (3). The mathematics learning outcomes of students after learning with the Cycle II contextual approach are in the moderate category with an average value of 68.67 from the highest score of 100 and the lowest value of 50.

Keywords: mathematics learning outcomes, contextual approach, and volume of cubes and beam 


\section{Pendahuluan}

Pada Peraturan Menteri Pendidikan Nasional Nomor 22 tahun 2006 tentang Standar Isi dinyatakan bahwa matematika merupakan ilmu universal yang mendasari perkembangan teknologi modern, mempunyai peran penting dalam berbagai disiplin dan memajukan daya pikir manusia. Perkembangan pesat di bidang teknologi informasi dan komunikasi dewasa ini dilandasi oleh perkembangan matematika di bidang teori bilangan, aljabar, analisis, teori peluang dan matematika diskrit. Untuk menguasai dan mencipta teknologi di masa depan diperlukan penguasaan matematika yang kuat sejak dini.

Mata pelajaran Matematika perlu diberikan kepada semua peserta didik mulai dari sekolah dasar untuk membekali peserta didik dengan kemampuan berpikir logis, analitis, sistematis, kritis, dan kreatif, serta kemampuan bekerjasama. Kompetensi tersebut diperlukan agar peserta didik dapat memiliki kemampuan memperoleh, mengelola, dan memanfaatkan informasi untuk bertahan hidup pada keadaan yang selalu berubah, tidak pasti, dan kompetitif.

Standar kompetensi dan kompetensi dasar matematika dalam dokumen ini disusun sebagai landasan pembelajaran untuk mengembangkan kemampuan tersebut di atas. Selain itu dimaksudkan pula untuk mengembangkan kemampuan menggunakan matematika dalam pemecahan masalah dan mengkomunikasikan ide atau gagasan dengan menggunakan simbol, tabel, diagram, dan media lain. Pendekatan pemecahan masalah merupakan fokus dalam pembelajaran matematika yang mencakup masalah tertutup dengan solusi tunggal, masalah terbuka dengan solusi tidak tunggal, dan masalah dengan berbagai cara penyelesaian. Untuk meningkatkan kemampuan memecahkan masalah perlu dikembangkan keterampilan memahami masalah, membuat model matematika, menyelesaikan masalah, dan menafsirkan solusinya.

Dalam setiap kesempatan, pembelajaran matematika hendaknya dimulai dengan pengenalan masalah yang sesuai dengan situasi (contextual problem). Dengan mengajukan masalah kontekstual, peserta didik secara bertahap dibimbing untuk menguasai konsep matematika. Untuk meningkatkan keefektifan pembelajaran, sekolah diharapkan menggunakan teknologi informasi dan komunikasi seperti komputer, alat peraga, atau media lainnya.

SD Inpres 33 Distrik Salawati Kabupaten Sorong terletak di Jalan Poros Katapop, dengan kriteria ketuntasan minimal untuk mata pelajaran matematika Kelas V adalah 60. Penulis mulai mengajar di SD Inpres 33 sejak tahun 1996 dan di tugaskan mengajar di kelas V.Saat penulis mengajar dijumpai siswa sulit memahami kubus dan balok terutama dalam menentukan atau menghitung volume. Hal tersebut disebabkan salah satunya karena dalam menyajikan materi pelajaran hanya bersifat abstrak, guru hanya menjelaskan, mencatat, dan dilanjutkan dengan mengerjakan soal latihan, sehingga siswa sulit untuk membayangkan dan membawa ke dalam dunia nyata atau pada hal-hal konkrit dalam kehidupan sehari-hari.Yang pada akhirnya siswa kurang tertarik pada mata pelajaran matematika, sehingga berakibat rendahnya prestasi/hasil belajar matematika khususnya pokok bahasan volume kubus dan balok.

Berdasarkan uraian diatas maka dilakukan penelitian untuk mengetahui peningkatan Hasil Belajar Matematika Pokok Bahasan Volume kubus dan balokbagi Siswa Kelas V di SD Inpres 33 Kabupaten Sorong melalui Pendekatan Kontekstual. 


\section{Metode Penelitian}

Penelitian ini merupakan penelitian tindakan kelas (classroom action research), yaitu pencermatan terhadap kegiatan belajar berupa sebuah tindakan, yang sengaja dimunculkan dan terjadi dalam sebuah kelas secara bersama.Penelitian ini dilakukan secara kolaboratif dan partisipatif. Secara partisipatif bersama-sama mitra peneliti melaksanakan penelitian langkah demi langkah. Selain partisipatif, peneliti dapat berkolaborasi dengan guru lain. Dalam penelitian tindakan kelas ini, guru bertindak sebagai pelaksana tindakan sedangkan peneliti bertindak sebagai kolaborator. Penelitian tindakan kelas ini dilakukan oleh peneliti, mencoba menemukan suatu gagasan yang kemudian diterapkan dalam upaya perbaikan pada praktik pembelajaran yang dilakukan. Dalam penelitian tindakan ini mencoba menerapkan variasi model pembelajaran yang baru yaitu pada model pembelajaran menggunakan Pendekatan Kontekstual yang diharapkan dapat memberikan perubahan ke arah perbaikan pada suatu proses pembelajaran. Dalam penelitian tindakan kelas ini terdiri atas rangkaian empat kegiatan yang dilakukan dalam siklus berulang. Empat kegiatan utama yang ada pada setiap siklus, yaitu : 1). Perencanaan (planning), yaitu persiapan yang untukpelaksanaan PTK. 2). Tindakan (acting), yaitu deskripsi tindakan yang akan dilakukan,skenario kerja tindakan, perbaikan kerja yang akan dilakukan dan prosedur tindakan yang diterapkan. 3). Observasi (observing), yaitu kegiatan mengamati dampak atastindakanyang dilakukan. Kegiatan ini dapat dilakukan dengan cara pengamatan, wawancara atau cara lain yang sesuai dengan data yang dibutuhkan. 4). Refleksi (reflecting), yaitu kegiatan evaluasi tentang perubahan yangterjadi atau hasil yang diperoleh atas data yang terhimpun sebagai bentuk dampak tindakan yang telah dirancang. Berdasarkan langkah ini akan dapat diketahui perubahan yang terjadi dan dapat dilakukan tindakan sehingga mampu mencapai perubahan atau mengatasi masalah secara signifikan.

\section{Hasil dan Pembahasan}

a. Siklus 1

1). Kondisi Awal dan Perencanaan

Sebelum penelitian tindakan dilaksanakan terlebih dahulu dilakukan pengamatan awal, agar mengetahui kondisi awal dan permasalahan pembelajaran yang ada di kelas. Dengan kata lain, adanya permasalahan di kelas itu yang nantinya akan menjadi fokus penelitian. Dari hasil pengamatan yang dilakukan oleh peneliti, prestasi belajar padamata pelajaran Matematika pokok bahasan volume kubus dan balok siswa Kelas V SD Inpres 33 Kabupaten Sorong dikatakan rendah karena masih ada 17 siswa yang nilainya di bawah 60 yang merupakan Kriteria Ketuntasan Minimal (KKM) yang telah ditentukan sekolah dengan melihat hasil ulangan harian. Hal ini disebabkan guru masih menggunakan metode ceramah dan monoton sehingga siswa menjadi pasif dan kurang aktif dalam mengikuti proses pembelajaran. Hal ini apabila tidak ditindaklanjuti tentu akan mengakibatkan proses pembelajaran tidak optimal dan mempengaruhi prestasi belajar.

\section{2). Hasil Observasi dan Pembahasan}

Selama kegiatan belajar mengajar berlangsung observer melakukan pengamatan secara langsung mengenai partisipasi yang ditunjukkan oleh siswa dalam mata pelajaran Matematika.Dalam penelitian ini, unsur-unsur yang termasuk dalam partisipasi siswa atau 
keaktifan siswa meliputi mendengarkan penjelasan Guru, mencatat penjelasan guru, memperhatikan pembelajaran, bertanya, menjawab pertanyaan, mengeluarkan pendapat, menghargai pendapat teman, refleksi/menjelaskan kembali. Maka dari indikator-indikator tersebut, hasil dari lembar pengamatannya dapa dilihat pada Tabel 1:

Tabel 1. Hasil Observasi Partisipasi Aktif Siswa pada Siklus 1

\begin{tabular}{lccc}
\hline \multicolumn{1}{c}{ Aspek yang diamati } & \multirow{2}{*}{$\begin{array}{c}\text { Jumlah } \\
\text { siswa }\end{array}$} & \multicolumn{2}{c}{ Partisipasi Aktif } \\
\cline { 3 - 4 } & total & Jumlah siswa & Persentase (\%) \\
\cline { 3 - 4 } & 30 & 10 & 33 \\
Mendengarkan Penjelasan & 30 & 12 & 40 \\
Mencatat penjelasan & 30 & 11 & 36 \\
Memperhatikan pembelajaran & 30 & 2 & 6 \\
Bertanya & 30 & 4 & 12 \\
Menjawab pertanyaan & 30 & 2 & 6 \\
Mengeluarkan pendapat & 30 & 4 & 12 \\
Menghargai pendapat teman & 30 & 1 & 3 \\
Mampu menjelaskan kembali & & & \\
\hline
\end{tabular}

\section{3). Hasil Tes}

Pada hasil analisis tes ini didapat data yang berupa angka-angka mengenai jumlah nilai yang diperoleh masing-masing siswa terhadap soal yang dikerjakan setelah menerapkan pendekatan kontekstual dalam proses mata pelajaran Matematika. Data yang diperoleh melalui tes dihitung jumlah nilai yang diperoleh masing-masing siswa dengan cara mengakumulasikan masing-masing nilai pada setiap item soal yang dijawab siswa.

Berdasarkan data yang ada sebelum perbaikan rata-rata sebesar 50,66, sedangkan pada siklus 1dapat diketahui sebesar 58,66. Hal ini menunjukkan bahwa terjadi peningkatan hasil belajar siswa setelah menggunakan pendekatan kontekstual pada mata pelajaran Matematika.Namun berdasarkan nilai siswa pada siklus I di atas, kriteria keberhasilan belum tercapai, karena masih terdapat 16 siswa belum mencapai KKM, sehingga perlu dilanjutkan dengan siklus berikutnya yaitu siklus II.

\section{4). Refleksi}

Dalam pembelajaran pada siklus I ini, tahap refleksi dilakukan oleh peneliti dan guru kolaborator untuk mengevaluasi hasil observasi partisipasi aktif siswa dan hasil dari pelaksanaan post test sebagai umpan balik setelah pembelajaran.Penggunaan pendekatan kontekstual meskipun belum maksimal, sebenarnya sudah menunjukkan partisipasi aktif siswa.Masih banyak siswa yang cenderung enggan untuk mengemukakan pendapat dan hal tersebut dikarenakan siswa belum terbiasa di dalam pembelajaran menggunakan pendekatan kontekstual, sehingga masih banyak siswa yang pasif dalam mengikuti pembelajaran.

Pada pelaksanaan pembelajaran menggunakan pendekatan kontekstual untuk meningkatkan partisipasi aktif siswa pada siklus I belum sepenuhnya terlaksana dengan baik.Hal ini terjadi, mungkin dikarenakan siswa masih canggung dengan pembelajaran menggunakan pendekatan kontekstual. Prestasi belajar pada siklus I juga belum 
menunjukkan hasil yang maksimal, meskipun telah banyak siswa yang memenuhi kriteria ketuntasan minimal tetapi masih ada juga siswa yang belum memenuhi.

Berdasarkan hasil refleksi tersebut, maka perlu adanya tindakan lanjutan untuk memperbaiki atau menyempurnakan pembelajaran dengan menggunakan pendekatan kontekstual. Dikarenakan belum tercapainya target tindakan yang diinginkan pada pelaksanaan tindakan pada siklus I, maka peneliti dan guru sepakat untuk melanjutkan tindakan pada siklus II.

\section{b. Silus II}

1) Pengamatan terhadap partisipasi aktif siswa (observasi)

Selama kegiatan pembelajaran berlangsung observer melakukan pengamatan secara langsung mengenai partisipasi yang ditunjukkan oleh siswa dalam mata pelajaran Matematika pokok bahasab volume kubus dan balok.Pada siklus II ini tingkat partisipasi aktif siswa sudah mulai menunjukkan adanya peningkatan yang relatif stabil dan hampir semua siswa sudah memperhatikan, berpartisipasi dan mengikuti proses pembelajan. Semua ini dapat dilihat dengan adanya peningkatan dari hampir semua aspek yang diamati. Hasil dari pengamatan siswa pada siklus II, dapat dilihat pada Tabel 2:

Tabel 2. Hasil Observasi Partisipasi Aktif Siswa pada Siklus 1 I

\begin{tabular}{lccc}
\hline \multicolumn{1}{c}{ Aspek yang diamati } & Jumlah & \multicolumn{2}{c}{ Partisipasi Aktif } \\
\cline { 3 - 4 } & siswa & Jumlah & Persentase \\
& total & siswa & \\
\hline Mendengarkan Penjelasan & 30 & 12 & 40 \\
Mencatat penjelasan & 30 & 15 & 50 \\
Memperhatikan pembelajaran & 30 & 13 & 43 \\
Bertanya & 30 & 5 & 16 \\
Menjawab pertanyaan & 30 & 7 & 23 \\
Mengeluarkan Pendapat & 30 & 3 & 10 \\
Menghargai Pendapat teman & 30 & 6 & 20 \\
Mampu menjelaskan kembali & 30 & 3 & 10 \\
\hline
\end{tabular}

\section{2) Hasil Tes}

Hasil tes didapat data berupa angka-angka mengenai jumlah nilai yang diperoleh masing-masing siswa terhadap soal yang dikerjakan setelah menerapkan pendekatan kontekstual pada proses mata pelajaran Matematika. Data yang diperoleh melalui tes dihitung masing-masing siswa dengan cara mengakumulasikan masing-masing nilai pada setiap item soal yang dijawab siswa. Berdasarkan rata-rata hasil belajar antara tes pada siklus I dan siklus II yang diketahui bahwa pada tes II mencapai rata-rata sebesar 68,67 mempunyai rata-rata lebih tinggi dibandingkan dengan rata-rata pada tes yang dilakukan di siklus 1 sebesar 58,66. Hal ini menunjukkan adanya terjadi peningkatan pada hasil belajar pada siklus II dalam mata pelajaran matematika. Berdasarkan rata-rata pada siklus II di atas, kriteria keberhasilan sudah tercapai karena lebih dari 85\% siswa telah mencapai KKM, bahkan 93,33\% siswa mencapai KKM ( 60 ), hal ini menunjukkan adanya pencapaian tingkat keberhasilan sesuai dengan kriteria keberhasilan yang telah ditetapkan. 


\section{3) Refleksi}

Pada tahap refleksi peneliti bersama guru mengevaluasi hasil dari tes dan observasi, dari hasil pengamatan dan refleksi di siklus II maka penerapan pendekatan kontekstual dapat meningkatkan partisipasi aktif dan prestasi belajar siswa. Pada hasil partisipasi aktif siswa, siswa telah berpartisipasi secara aktif dalam pembelajaran dan keaktifan siswa pada proses pembelajan berlangsung dapat dilihat pada dokumentasi berupa foto-foto yang telah terlampir dalam lampiran, sedangkan pada hasil belajar semua siswa sudah mencapai ketuntasan yang telah ditetapkan yaitu memperoleh nilai $\geq 60$ untuk masing-masing siswa pada siklus ke II yaitu mencapai rata-rata 68,67. Jadi dari hasil pengamatan dan refleksi di siklus II penggunaan pendekatan kontekstual dapat meningkatkan partisipasi aktif dan prestasi belajar siswa.Hal ini dikarenakan dengan menggunakan pendekatan kontekstual, siswa lebih tertarik dan mempunyai motivasi yang tinggi untuk belajar.Keunggulan yang ada perlu dipertahankan untuk mendukung peningkatan dalam penggunaan media pembelajaran selanjutnya.Sedangkan beberapa kelemahan dalam media pembelajaran audio visual perlu diperbaiki untuk pertemuan selanjutnya.Berdasarkan hasil tes dan hasil observasi dari siklus II yang telah terjadi peningkatan dari siklus I, peneliti dan guru sepakat bahwa penelitian ini tidak dilanjutkan ke siklus III.

\section{Kesimpulan dan Saran}

Berdasarkan hasil analisis data dan pembahasan yang telah peneliti lakukan, aktivitas belajar siswakelas V di SD Inpres 33 Kabupaten Soronguntuk mata pelajaran Matematika, dapat ditarik kesimpulan sebagai berikut: 1. Penerapan pembelajaran dengan menggunakan pendekatan kontekstualdapatmeningkatkan hasil belajar matematika pada siswamateri volume kubus dan balok kelas $\mathrm{V}$ dilihat dari adanya peningkatan persentase. 2. Peningkatannya dapat dilihat dari hasil observasi pada siklus I dan siklus II. Pada aspek mendengarkan penjelasan siklus I ke siklus II. Begitupun pada aspek mencatat, memperhatikan pembelajaran, aspek bertanya, aspek menjawab pertanyaan, aspek mengeluarkan pendapat, aspek menghargai pendapat, aspek mampu menjelaskan kembali. Hal ini menunjukkan bahwa terjadi peningkatan terhadap partisipasi aktif siswa pada pembelajaran dengan pendekatan yang diterapkan pada kelas V di SD Inpres 33 Kabupaten Sorong. 


\section{Daftar Pustaka}

DepdiknasRI, 2006. Permendiknas RI Nomor 22 Tahun 2006, tentang Standar Isi Kurikulum Tingkat Satuan Pendidikan. Jakarta.

..........., 2006. Permendiknas RI nomor 23 Tahun 2006 Tentang Standar Kompetensi Lulusan Kurikulun Tingkat Satuan Pendidikan . Jakarta.

Muhkal, Mappaita, 2007. Strategi Belajar Mengajar Matematika “Catatan Kuliah“, FMIPA, UNM Makassar.

Nana Sudjana. (2002). Penilaian Hasil Proses Belajar Mengajar. Bandung: PT. Remaja Rosdakarya.

Riduwan. (2009). Skala Pengukuran Variabel-Variabel Penelitian. Bandung: Alfabeta.

Suharsimi Arikunto. (2009). Dasar-dasar Evaluasi Pendidikan (Edisi Revisi, cetakan 7). Jakarta: Bumi Aksara

. (2013). Penelitian Tindakan Kelas. Jakarta : Bumi Aksara.

Susilo. (2007). Panduan Penelitian Tindakan Kelas. Yogyakarta: Pustaka Book Publlisher.

Tim, 2001. Kamus Besar Bahasa Indonesia, Balai Pustaka. Jakarta.

Wina Sanjaya, 2007. Strategi Pembelajaran Berorientasi Standar Proses Pendidik. Kencana, Jakarta. 